\title{
Implementasi Integrasi Tani Tenak (Studi Kasus di Desa Ngino Kecamatan Plemahan Kabupaten Kediri)
}

\author{
Nur Solikin ${ }^{1}$, Erna Yuniati $^{2}$, Dianita Sugiartanti ${ }^{3}$ \\ ${ }^{1,2,3}$ Fakultas Peternakan Universitas Nusantara PGRI Kediri \\ Email: ${ }^{1}$ nursolikin@unpkediri.ac.id, ${ }^{2}$ ernayuniati69@yahoo.com, \\ 3dianita_sugiartanti@yahoo.com
}

\section{Tersedia Online di \\ http://www.jurnal.unublitar.ac.id/ index.php/briliant}

\section{Sejarah Artikel}

Diterima pada 17 Juli 2017

Disetuji pada 9 Oktober 2017

Dipublikasikan pada 13

November 2017 Hal. 424-428

Kata Kunci:

Integrasi Tani Ternak, Ngino

Plemahan Kediri.

\section{DOI:}

http://dx.doi.org/10.28926/briliant .$v 2 \mathrm{i} 4.83$

\begin{abstract}
Abstrak: Pertumbuhan ekonomi masyarakat pedesaan akan bisa terangkat jika pola pengembanga dilakukan melalui pengintegrasian sektor pertanian dan peternakan. Kegiatan ini bertujuan mengetahui tingkat pengetahuan dan ketrampilan anggota kelompok tani/ternak dalam memanfaatkan limbah pertanian untuk peternakan dan pemanfaatan limbah peternakan untuk sektor pertanian. Metode yang digunakan dalam kegiatan ini partisipatoris. Hasil menunjukan responden sejumlah 60 orang menyatakan bahwa 10 persen dari anggota kelompok ternak yang sudah memanfaatkan limbah pertanian diproses menjadi pakan ternak dan 90 persen memanfaatkan limbah ternak tanpa diproses atau hanya disimpan atau langsung diberikan ke ternak. Dalam pemanfaatan limbah peternakan 5 persen yang mengolah limbah ternak menjadi pupuk bokasih dan 75 persen tidak diolah dibiarkan saja kalau kering langsung dibuang di lahan pertanian dan 20 persen yang lain dijual kepada yang membutuhkan. Simpulannya adalah pola pengintegrasian sektor pertanian dan peternakan di Desa Ngino Kecamatan Plemahan Kabupaten Kediri masih kurang dan perlu dikembangkan.
\end{abstract}

Sektor pertanian selain menghasilkan produk utama berupa padi, jagung, sayuran selain itu juga menghasilkan produk samping yang berupa limbah pertanian yang dapat dimanfaatkan untuk pakan ternak. Pemanfaat limbah pertanian untuk ternak akan memberi kontribusi terhadap pendapatan rumah tangga petani. Sumberdaya pedesaan yang berasal dari pertanian dapat dijadikan sebagai pakan ternak yang bergizi tinggi apabila dilakukan proses dan perlakuan tertentu. Mekanisme pengolahan perlu untuk diinformasikan kepada kelompok tani-ternak. Limbah ternak yang dipelihara agar lebih bisa bermafaat dan menambah keuntungan bagi petani juga perlu diberikan ketrampilan dan dorongan pengunaannya.

Kelompok tani melaksanakan fungsi sebagai kelas belajar yaitu kelompok yang dapat menjadi media untuk meningkatkan pengetahuan, keterampilan dan sikap anggota, sebagai unit produksi yaitu kelompok dapat mencapai skala ekonomi yang efesien dalam memproduksi usahanya serta sebagai wahana kerjasama diantara sesama anggota, kerjasama dengan kelompok atau pihak lain sehingga produktivitas kelompok dan masing-masing anggota meningkat juga sebagai kelompok usaha artinya sebagai suatu kesatuan usaha 
yang dijalankan sehingga mampu mencari dan memanfaatkan berbagai peluang dan kesempatan berusaha.

Petani dan peternakan dikelompokkan menjadi tiga komponen utama yang menjadi penyebab, yakni (1) kompetensi petani/peternak rendah (kompetensi teknis dan kompetensi wirausaha), (2) keberdayaan petani/peternak rendah dan (3) berbagai faktor internal dan eksternal sebagai pendukung utama dan penunjang dalam pengembangan usaha perlu mendapat dukungan dari berbagai unsur yang terkait.Dalam pemberdayaan ekonomi masyarakat pedesaan, sektor pertanian harus menjadi sasaran utama.Sektor ini harus dijadikan pijakan yang kokoh sehingga di pedesaan bisa tercapai swasembada berbagai produk pertanian, terutama pangan, sebelum memasuki era industrialisasi.Lebih spesifik, ketahanan pangan lokal harus tercapai lebih dahulu (Basri, M. 2007).

Aktifitas ekonomi pada sektor pertanian dan memposisikan ternak sebagai usaha sampingan menjadi budaya di pedesaan termasuk di desa Ngino kecamatan Plemahan. Sektor pertanian dan peternakan dalam pembangunan ekonomi Kabupaten Kediri berperan dalam beberapa hal antara lain (a). Penopang pertumbuhan ekonomi (mempunyai kontribusi terhadap pendapatan masyarakat), (b) Penyedia lapangan kerja (c) Penyedia kebutuhan protein hewani dan kaya nutrisi untuk konsumsi manusia, (d). Pendorong tumbuhnya sektor industri.

Pada bidang peternakan penyebaran informasi teknologi dari berbagai sumber sangat kurang, sehingga pengetahuan petani mengenai manajemen usaha sangat kurang. Yohanes G. Bulu,dkk, (2003) mengemukakan bahwa peranan kelompok ternak sapi potong di Nusa Tenggara Barat, khususnya dikabupaten Lombok tumbuh secara parsial. Artinya kelompok ternak sapi potong itu sudah ada sejak lama dan berkembang secara turun temurun, baru beberapa tahun terakhir ini pemerintah turut membenahi serta memberikan informasi teknologi pengembangan ternak.

Dalam hal ini substansi yang menjadi perhatian seberapa besar kelompok tani/ternak memanfaatkan limbah pertanian dan peternakan sehingga akan tercipta saling menguntungkan dan mendukung,dan akan memperoleh nilai tambah bagi petani/peternak. Sehingga sektor ekonomi pedesaan dapat tumbuhkembang dan mampu mengurangi dampak sosial ekonomi pedesaan.

\section{METODE}

Pembangunan masyarakat akanberhasil jika bertumpu pada peoplecentered, participatory, empowering, dan sustainable. Menurut Kartasasmita (1996) upaya yang dilakukan di dalam memberdayakan masyarakat dapat memiliki dimensi: (1) menciptakan suasana atau iklim yang memungkinkan masyarakat berkembang (enambling), (2) memperkuat potensi atau daya yang dimiliki oleh masyarakat (empowering). Perkuatan ini meliputi langkah-langkah nyata, dan menyangkut penyediaan berbagai masukan (input), serta pembukaan akses ke dalam berbagai peluang (opportunities) yang akan membuat masyarakat makin berdaya, (3) memberdayakan mengandung pula arti melindungi.

Metode yang digunakan dalam kegiatan ini partisipatoris, Masyarakat tidak dilihat sebagai obyek melainkan subyek dari pembangunan yang dilakukan, sehingga penekanan partisipasi dari masyarakat menjadi lebih menonjol dalam mendapatkan data diperoleh dari anggota kelompok tani dan ternak melalui wawancara dan angket. 


\section{HASIL}

Kelompok tani/ternakmargo utomo merupakan salah satu kelompok petani yang ada di desa ngino kecamatan plemahan kabupaten kediri. Beranggotakan lebih dari 60 petani produktif dengan 90\% memiliki ternak sebagai usaha sampingan.Ternak yang dipeliharan berupa sapi dan kambing dengan penguasaan ternak 2-3 ekor per petani. Dari 60 anggota hampir separoh dari pengurusnya adalah pemuda (umur 26 - 40 tahun) dengan pendidikan Sekolah Menengah Pertama (SMP) - Sekolah Menegah Atas (SMA) dan ada 1 yang berpendidikan Strata $1(\mathrm{~S} 1)$.

Dari total responden tersebut merupakan petani kecil yakni dengan kepemilikan lahan 0,25 Ha dan kepemilikan ternak 2-4 Satuan ternak. Keterlibatan dalam berkelompok sebagian besar bukan disebabkan oleh motivasi untuk menyatukan diri untuk merubah dan mencapai kesejahteraan bersama. Mereka tergabung hanya dikarenakan kebutuhan faktor produksi misalnya keperluan pupuk yang di distribusi kelompok, bantuan dari pemerintah lewat kelompok. Upaya mengkombinasikan sektor pertanian dan peternakan juga masih kurang berjalan secara optimal. Seluruh responden dimintai tanggapan mengenai kebiasaan dalam memanfaatkan limbah pertanian untuk pakan ternak, adapun hasilnya sebagai berikut pada tabel 1:

Tabel 1. Kebiasaan petani memanfaatkan limbah pertanian (komoditas Jagung, Padi) untuk pakan ternak

\begin{tabular}{lcc}
\hline \multicolumn{1}{c}{ Jawaban } & Jumlah responden & Prosentase (\%) \\
\hline $\begin{array}{l}\text { Jerami/ tebon tererlebih dahulu sebelum diberikan } \\
\text { ke ternak }\end{array}$ & 6 & 10 \\
\hline $\begin{array}{l}\text { Jerami/tebon hanya dikumpulkan tanpa dip roses } \\
\text { langsung diberikan ke ternak }\end{array}$ & 54 & 90 \\
\hline Sumber : data primer diolah, 2017 & &
\end{tabular}

Berdasarkan data pada tabel 1 menunjukan bahwa pemanfaatan limbah pertanian sebagai sumber pakan tenak masih sangat kurang, hal ini disebabkan oleh beberapa faktor diantaranya : 1) petani belum mengetahui cara pengolahan dari yang sederhana sampai yang menerapkan teknologi mikrobiologi, 2) tidak memiliki banyak waktu dan tenaga karena konsentrasi pada sektor pertanian semata artinya berternak sebatas sampingan, 3) tidak memiliki lahan yang cukup dan uang yang terbatas.

Dalam memanfaatkan limbah peternakan sebagai pupuk untuk lahan pertanian, dapat dikategorikan masih rendah. Sebagaimana tertera pada tabel 2.

Tabel 2. Kebiasaan petani memanfaatkan limbah perternakan untuk lahan pertanian

\begin{tabular}{lcc}
\hline \multicolumn{1}{c}{ Jawaban } & Jumlah responden & Prosentase (\%) \\
\hline Mengolah limbah ternak menjadi pupuk bokasih & 3 & 5 \\
\hline $\begin{array}{l}\text { tidak diolah dibiarkan saja kalau kering langsung } \\
\text { dibuang di lahan pertanian }\end{array}$ & 45 & 75 \\
\hline diganti/jual kepada yang membutuhkan & 12 & 20 \\
\hline
\end{tabular}

Sumber : data primer diolah, 2017 


\section{PEMBAHASAN}

Pengetahuan dan keterampilan petani sangat berpengaruh terhadap pola pandang dalam pengembangan usaha khususnya pada sektor pertanian dan peternakan. Motivasi mengembangkan usaha menjadi lebih besar masih menjadi persoalan di pedesaan, hal ini sejalan dengan penelitian nur solikin (2016) yang menyatakan bahwa tingkat jiwa wirausaha pada kelompok tani/ternak di kabupaten kediri masih rendah terkendala oleh motivasi dalam menjalankan usaha bersifat tradisional.

Usaha pertanian yang sebelumnya terlepas dari peternakan semestinya menjadi mutlak diusahakan secara terpadu mengingat sejumlah manfaat yang diperoleh jika peternakan-pertanian dikelola secara bersama-sama pada waktu yang sama di lingkungan sama. Ternak yang memerlukan dari output proses produksi pertanian (biomas), disisi lain proses produksi pertanian memerlukan input dari ternak berupa pupuk kandang maupun tenaga ternak yang dapat dimanfaatkan. Oleh karenanya peranan masing-masing (peternakan dan pertanian) dapat membantu pencapaian tujuan produksi masing-masing. Dengan kata lain, peternakan membutuhkan produksi pertanian dan sebaliknya pertanian membutuhkan produksi peternakan. Ini berarti interaksi keduanya yang terjadi tidak hanya berdampak langsung pada hasil produksi tetapi juga karenanya dapat memberi kontribusi dalam pelestarian sistem lingkungan lebih-lebih lingkungan tempat tinggal peternak maupun peternak.

Jerami padi / tebon jagung merupakan limbah pertanian yang tersedia melimpah sebagai bahan baku pakan perlu ditingkatkan nilai nutrisinya agar nilai degradabilitas oleh mikroba rumen menjadi lebih tinggi. Peningkatan nilai nutrisi dilakukan melalui fermentasi dengan menggunakan campuran mikroba dan bahan lain yang mampu menunjang mikroba penghasil enzim pemecah serat. Jerami fermentasi dapat memberikan energi dalam bentuk asam lemak mudah terbang bagi ternak dan meningkatkan efisiensi metaboliesma zat pakan.

Peternak jarang melakukan fermentasi limbah pertanian di sebabkan sebagian besar mereka memiliki waktu yang terbatas karena beternak hanya sebagai pekerjaan sampingan dan tenaga yang terbatas juga menjadi salah satu penghambat. Sebagian ada yang beralasan bahwa dengan melakukan fdermentaasi harus menambah biaya yang dikeluarkan.

Dalam pemanfaatan limbah peternakan yang dijadikan pupuk juga tergolong sedikit peternak yang mengolah limbah ternak menjadi pupuk dengan mengunakan teknologi mikroba, teknik yang dipakai masih konvensional yakni dengan langsung membawa kotoran ternak ke sawah. Sebagian besar belum pernah mengolah limbah ternak menjadi bokasi/pupuk terfermentasi. Alas an yang disampaikan hamper sama yaitu tidak punya waktu, tenaga dan biaya untuk memprosesnya.

\section{KESIMPULAN}

Hasil yang diperoleh dapat dinyakan bahwa pemanfaatan limbah menjadi pakan ternak masihrendah terbukti hanya 10 persen dari anggota kelompok ternak yang sudah memanfaatkan limbah pertanian diproses menjadi pakan ternak dan 90 persen memanfaatkan limbah ternak tanpa diproses atau hanya disimpan atau langsung diberikan ke ternak. Dalam pemanfaatan limbah peternakan juga tergolong rendah 5 persen yang mengolah limbah ternak menjadi pupuk bokasih 
dan 75 persen tidak diolah dibiarkan saja kalau kering langsung dibuang di lahan pertanian dan 20 persen yang lain diganti/jual kepada yang membutuhkan. Artinya pola pengintegrasian sektor pertanian dan peternakan masih sangat perlu dikembangkan dan ditingkatkan ketrampilan sehingga ekonomi pedesaan bisa optimal.

\section{SARAN}

Beberapa hal yang dapat disarankan dari hasil ini, (1) Perlu disosialisasikan pemanfaat limbah ternak dan pertanian dalam mewujudkan pertanian terintegrasi oleh pihak yang terkait. (2) Perlu dilakukan pelatihan teknik pembuatan pakan ternak dan pemanfaatan limbah ternak menjadi pupuk/bokashi.

\section{DAFTAR RUJUKAN}

Basri, M. 2007. Desa dan Kemiskinannya,(online) diakses 9 Januari 2017

Kartasasmita, G. 1996. Pemberdayaan Masyarakat: Konsep Pembangunan yang Berakar pada Masyarakat. Bandung: Institut Teknologi Bandung.

Pranadji,T. 2000. Beberapa Aspek Untuk Antisipasi Pembangunan Pertanian Abad 21. Makalah disampaikan pada Pelatihan, Pemahaman Aspek Sosial dan Budaya Masyarakat Dalam Perencanaan dan Penerapan Teknologi. Kerjasama Jurusan Sosial Ekonomi Pertanian. Sumedang: Fakultas Pertanian UNPAD.

Solikin, N dan Edy Djoko S. 2016. Entrepreneurship Kelompok Tani Ternak Studi Kasus Di Kabupaten Kediri. JuPEKO. STKIP PGRI Tulungagung. Yohannes, G. et al. 2003. Pendekatan Sosial Budaya Dalam Pengembangan Sistem UsahataniTanaman-Ternak diPulauLombokNusaTenggaraBarat. 